Received 13 January 2021 Accepted 13 July 2021

Link to DOI:

10.25220/WNJ.V04.i2.0005

Journal Website: www.worldnutrijournal.org

\section{Dietary intake and obesity in oil and gas workers: A literature review}

\author{
Nur Lailatuz Zahra ${ }^{1}$, Dian Novita Chandra ${ }^{1}$
}

1. Department of Nutrition, Faculty of Medicine, Universitas Indonesia-Dr. Cipto Mangunkusumo General Hospital, Jakarta, Indonesia

\begin{abstract}
Introduction Working in oil and gas industries was found to be associated with unhealthy lifestyle, obesity, and non-communicable diseases (NCDs). This study aimed to systematically review the dietary intake, obesity status, and identify possible workplace health promotion strategies for oil and gas setting.

Methods: This literature review was conducted through a comprehensive search of Scopus database. Search terms included diet (and synonym), worker (and synonyms), oil and gas (and synonym). The search was limited to paper in English and Indonesian. Combinations of the keyword yielded 76 papers, of which 13 articles were relevant.

Results: Reviewed studies implied that diet consist high amount of fat, particularly saturated fat, and cholesterol, with low intake of dietary fiber. Fatigue, boredom, and inadequate sleep may influence unhealthy food choices. All studies revealed that mean BMI among oil and gas workers was found to be higher than general adult population, ranged from 24 to almost $30 \mathrm{~kg} / \mathrm{m}^{2}$. Possible health promotion components to be modified are knowledge and beliefs, self-care, peer support, food availability and time restriction at cafeterias.

Conclusion: It is confirmed that obesity and NCDs prevalence were high in oil and gas worker, however the updated studies addressing their dietary intake are needed. Health promotion initiative made by oil and gas company are unlikely to be found in scientific paper. There is a need for more health promotion program that scientifically designed so that the outcome and cost effectiveness can be measured properly
\end{abstract}

Keywords dietary intake, obesity, oil and gas worker 


\section{Introduction}

Oil and gas industries play an important role in world economic development. Crude oil and natural gas accounted for $32.0 \%$ and $22.2 \%$ of the world total primary energy supply in 2017. Industrial use, commercial and public services, transportation, and residential were several sectors of oil and gas consumption share. ${ }^{1}$ Because of high demand for flexibility and productivity in oil and gas workforce, workers are usually engaged in 12-hour work schedule with 12-14 days of rotations. ${ }^{2}$

Engaged in shift work has long been identified as occupational hazard, with a rising body of evidence showing an association between shift work and adverse health concern that include metabolic disorder, obesity, and chronic diseases. ${ }^{3-5}$ Due to unusual working schedule, shift worker may pose additional risk of unhealthy lifestyle habits, including poor diet. ${ }^{6}$ Apart from most common risk of working on shift, they are exposed to stressor that are specific to the workplace setting, such as vibration, noise, adverse weather condition, confined living and working areas that may influence higher risk to metabolic disorder and unhealthy lifestyle. ${ }^{7}$ Recent study found that oil and gas worker experienced heavy mental workload and even tends to very heavy. ${ }^{8}$

Study in Italian oil and gas workers showed that during ten years of follow-up, there were significant increase in cardiovascular diseases risk factors, including obesity and hypercholesterolemia. ${ }^{9}$ Growing body of evidence revealed that it is easier to find obese worker in oil and gas population, compared to general adults' population. ${ }^{10-12}$ Foods in oil and gas workplace are usually available at all hours throughout the days. Plentiful of pleasant energy-dense foods prepared with significant amount of salt and fat are served. Therefore, their diet are known to be high in saturated fat, cholesterol, and sodium. ${ }^{10}$ However, studies regarding their eating habits and nutrition intake as the key aspect of obesity prevention were rather limited.

The consequences of unhealthy eating habits and obesity may influence working performance through back pain, stress, and non-communicable diseases. ${ }^{13}$ Particularly in petrochemical industries, $80 \%$ of obese workers were more likely to have higher absences days per year compared to normal weight employees. This was attributable to illness due to cardiovascular diseases. Around 1.8 million USD of economic lost were attributable to obesity related illness in this population. These impacts will continue to increase unless actions are taken. ${ }^{14}$

Worksite as a place and environment where employees spend significant amount of time and engaged into several habits was a promising setting for health promotion. Workplace health promotion and primary prevention was found to be effective in improving worker health behaviors and clinical outcomes. ${ }^{15}$ Moreover, it is positively associated with worker presenteeism ${ }^{16}$ and productivity ${ }^{17}$. However, the results were varied based on the study population, study characteristic and methodological quality. ${ }^{18}$

As a leading industry in economic development, oil and gas companies are keen to improve the health of their employees. ${ }^{14}$ Therefore, worksite health promotion supposed to be applicable. Furthermore, there were occupational doctor or occupational nurse within the working location ${ }^{19}$, increasing the support system of health promotion in this industry.

This literature review aimed to systematically summarize and appraise the literature on eating habits, dietary intake and obesity in oil and gas workers, explore potential variables associated with those habits and identify possible workplace health promotion strategies in this population.

\section{Methods}

A systematic search was conducted on 29/07/2020 through Scopus website. The combination of keywords used were: TITLE (worker OR employee OR workforce) AND TITLE-ABS-KEY (\{oil and gas\} OR petrochemical OR offshore OR onshore OR \{oil industry\} $O R$ \{oil refinery\}) AND ALL (diet OR eating OR \{food choice\} OR nutrition OR nutrient OR nutritional).

Studies were considered eligible if they were conducted in oil and/or gas workforce, if the study was targeted both oil and/or gas workers and other workers, only subgroup analyses of oil and/or gas workers included in this research. Studies should be an original research, including but not limited to randomized controlled trials (RCT), quasi- 
experimental studies, longitudinal and crosssectional studies. This review was limited to papers in English and Indonesian. Due to lack of references in the topics of eating habits among petrochemical worker populations, all study fulfilled inclusion criteria and published since the instinctive periods were included in analysis.

Identified studies was then screened based on its title and abstract. Full papers were obtained and assessed for eligibility in the second step of screening. Studies were excluded due to not measured dietary/nutrition outcome (18), not targeted oil and/or gas worker (2) and duplicate studies (6). Snowball checking on the reference list from included studies and manual search on Google Scholar was conducted to ensure that no applicable studies had been omitted.

The publications were classified to two main categories: 1) Studies exploring outcomes regarding dietary intake, 2) Studies exploring outcomes regarding obesity, 2) Studies exploring outcomes regarding the improvement of diet, eating habits and obesity among oil and/or gas workers. The following information was extracted: first author, year of publication, study design, study location, characteristics of participants, diet/obesity outcome and measurements, influencing factor, and key findings.

The methodological quality of each study was assessed using an Effective Public Health Practice Project (EPHPP) "Quality Assessment Tool for Quantitative Studies" that evaluates six main domains: (1) selection bias; (2) study design; (3) confounders; (4) blinding; (5) data collection method; and (6) withdrawals/dropouts, each of which can be rated as strong, moderate, and poor. An overall score was obtained for each study by adding up the separate section rating (see Additional file 1). The literature review was conducted in accordance with the Preferred Reporting Items for Systematic Reviews and Meta-Analyses (PRISMA) guidelines.

\section{Results}

The literature search through Scopus website yielded 76 papers, after first and second screening, 13 articles met the inclusion criteria. Most studies were cross-sectional (8), three longitudinal studies, one experimental study and one qualitative study. Studies were published between 1992 and 2020. The study populations came from different geographical regions: seven were European studies $(\mathrm{UK}=3$, Norway $=1$, Finland $=1$, Italy $=1$, Brazil=1) five were Asian studies (Iran=3, Indonesia=1, Kuwait=1) and one study conducted in Australia. Sample size ranged from 16 to 3282 participants. The study participants were dominated by male with percentage of males ranging from 85 to $100 \%$. The detailed characteristics of study assessing dietary intake shows in Table 1.

\section{Dietary intake}

Four studies explored dietary intake of oil and/or gas workers (Christina et al 2011; Hassani et al. 2020; Heath et al. 2016; Oshaug, Østgård, and Trygg 1992). Two studies are using one day 24-hour dietary recall (Christina and Sartika 2011; Oshaug, Østgård, and Trygg 1992) and two studies are using a validated semi quantitative Food Frequency Questionnaire (FFQ) (Hassani et al. 2020; Heath et al. 2016).

Regarding the type of foods consumed, the study by Oshaug and collagues ${ }^{20}$ found that animal protein sources food, particularly high in meat and low in fish, dairy product and fried fries were important foods in worker's dietary pattern. Two studies (Hassani et al. 2020; Oshaug, Østgård, and Trygg 1992) identified that sweets and snacks, sweetened beverages, coffee, and tea with added sugars were snacking choices among oil and gas population.

The analysis of the diet implied high intake of fat, particularly saturated fat and cholesterol; with low intake of dietary fiber. In line with excessive intake of fats, the availability of fat sources foods in oil and gas setting was also high. ${ }^{20}$ Study compared nutrient intake of oil and gas workers with other groups of workers found significant, positive association between job-related factor such as shift schedule, fatigue, and sleep duration with dietary fat intake of workers. $^{21}$

\section{Obesity}

Eight studies reported mean Body Mass Index (BMI) and obesity status among oil and/or gas 
workers (Al-Asi 2003; Baghshini et al. 2017; Christina, Ayu, and Sartika 2011; Heath et al. 2016; Mannocci et al. 2015; Parkes 2003; Poorabdian et al. 2013; Stewart et al. 2017). All studies revealed that mean BMI among oil and gas workers was found to be higher than general adult population, ranged from 24 to almost $30 \mathrm{~kg} / \mathrm{m}^{2}$. The study reporting lowest BMI was an observative cross-sectional study of UK offshore workers at baseline years of 1984 (24.9 $\left.\mathrm{kg} / \mathrm{m}^{2}\right)^{10}$ and the highest reported average BMI was from Iranian male petrochemical workers $\left(29.93 \pm 7.3 \mathrm{~kg} / \mathrm{m}^{2}\right)^{22}$. Overall prevalence of obesity ranged from $12.7 \%$ from Italian oil and gas and energy company worker ${ }^{12}$ to $49.5 \%$ from Indonesian onshore oil and gas workers ${ }^{23}$

Observative cross-sectional studies reported that mean BMI and obesity prevalence increased during follow-up period. ${ }^{10,24}$ Variables found to be significantly associated with BMI among oil and gas worker were age, gender, marital status, level of education, employment status, type of work, job control, job demand, smoking, physical activity, and dietary intake, however the direction of these associations varied between studies. ${ }^{12,22-25}$

Two studies found that older workers were more likely to have obesity, when compared to younger worker (Christina et al 2011; Mannocci et al. 2015). Nevertheless, one study found distinct results, in UK offshore population, younger workers have higher risk to be obese. Additionally, this study by Parkes ${ }^{24}$ also found that workers with lower education and involved in sedentary job were prone to be obese. These results were inconsistent with separates studies that found workers with higher level of education $^{23}$ and worked in the field ${ }^{25}$ have higher risk of obesity, compared to workers with lower education and office workers, respectively.

\section{Improvement of dietary intake and obese status}

Three studies investigate the efforts to improve diet, eating habits and obese status among oil and/or gas workers were identified. All three intervention were formed nutrition education/consultation session in the workplace, but in different strategies (Hassani et al. 2020; Talvi, Järvisalo, and Knuts 1999; Viterbo et al. 2019).

The study by Talvi et a ${ }^{26}$ gives a counselling session designed based on workers' health needs.
This prospective cohort study was well received by the company, however for three years follow-up only physical fitness improved, there were no significant changes in dietary habits and obesity.

The study by Viterbo et $\mathrm{al}^{27}$ aimed to increased health self-care of workers towards annual interdisciplinary health promotion sessions for four years. Groups receiving health promotion showed significant improvement in physical activity, the obesity prevalence was decreased, but not significant.

The study by Hassani et $\mathrm{al}^{28}$ have shortest periods, three months. However, the quality of this study was better, since this study was developed as a randomized clinical trial study. Education sessions was not only targeted the workers, but also their family. Intensive meetings with nutritionist during that amount of time and massive follow-up resulting significant improvement in nutritional knowledge, dietary practices, body weight and BMI.

\section{Discussion}

Based on available literature found in this review, the population of oil and gas workers from both developed and developing countries were engaged into poor diet quality, high prevalence of obesity and high risks of NCDs. Included studies identified association between obesity and age, gender, marital status, level of education, employment status, type of work, job control, job demand, smoking, physical activity, and dietary intake, however, the direction of these associations varied between studies. Potential intervention to improve diet, eating habits and obesity among oil and gas workers consist of informational messages, behavioral and social skills, environmental changes, and policy.

Decades ago, study already predicted that dietary patterns of oil-worker may contribute to the development of coronary heart diseases. ${ }^{20}$ Unfortunately, dietary assessment was not common to be assessed compared to BMI or anthropometric measurement, in spite of the close association between diet and BMI. Given that the most existing studies were cross-sectional, we assumed that the limited time and resources were obstacles to obtain a valid dietary data.

Nevertheless, from those limited data we managed to summarize similar patterns that the diet 
of oil and gas workers consist of high intake of fat and low intake of fiber. Latest systematic review about shift work and eating habits corresponds these finding, additionally, this review managed to conclude that shift worker has poor diet quality with altered meal patterns such as skipping some meals and eat more food at unusual times. ${ }^{6}$ However, another systematic review shows that the energy and macronutrient intakes of shift worker were not different with day workers. This review suggest that it could be the meal timing, food choice and energy distribution between meals that varies between shift workers and fixed day workers. ${ }^{29}$

Contribution of total fat (saturated fat) towards energy intake (\%) from Norwegian oil-worker, Indonesian onshore oil and gas worker, and Australian oil and gas worker were 44.0 (17.0), 32.7, and 34.5 (14.1), respectively. Meanwhile daily cholesterol and dietary fiber intake were $755 \mathrm{mg}$ and $19 \mathrm{~g} ; 366 \mathrm{mg}$ and $13 \mathrm{~g}$ for Norwegian and Indonesian oil and gas workers, respectively ${ }^{20,21,23}$. Intake of other nutrients may be unique and specific to the country characteristic, for instance most of the Norwegian oil-workers consumed calcium and vitamin $\mathrm{D}$ at its recommended amounts (or above), when it is not the case for other countries. ${ }^{20}$

Dietary fiber intake was half of the recommended value and percentage of saturated fat intake was exceeded its recommended intake $(\leq 10 \%$ of energy). ${ }^{30}$ While compared to other worker, this value was slightly lower than night shift worker. Oil and gas worker usually have 12-hour long working hours for 12-14 consecutive days, being attached to those shift and rotation found to be associated with adverse lifestyle habits such as lack of sleep and excess fatigue that resulting poor dietary intake. ${ }^{21}$ Additionally, the results from qualitative study shows that workers were less likely to eat healthy food if they were tired or bored. ${ }^{19}$ Moreover, this could be a two direction of association since a cohort study found that being overweight and obese were associated with higher job demand and low control towards their jobs (poor job strains) that linked with fatigue and depression. ${ }^{22}$

Recent systematic review revealed that engaged in shift work had negative association with nutritional intake. ${ }^{3}$ It is increased the possibility of being overweight/obese with overall odds ratio was 1.23 and higher chances to develop abdominal obesity. ${ }^{5}$ Probably due to unhealthy sleeping habits and eating at abnormal circadian times that resulting alteration in metabolism pathways, shift worker also has higher risk of diabetes and cardiovascular diseases. ${ }^{31}$ Another systematic review also found significant relationship between obesity, binge eating and depression. ${ }^{4}$ These findings, implied that when aiming to improve dietary habits of workers, it is important to maintain optimal sleep quality and physiological health of workers', for instance through fatigue and workload management.

The outcome measurement of obese status differed between one study that used BMI cut off for Asian population (Obese: $\mathrm{BMI} \geq 25)^{23}$, while the rest of studies used BMI cut off for general population (Obese: $B M I \geq 30$ ). Measurement of central obesity was less discussed, although some studies measure workers waist-circumference. Several demographic variables were found to be significantly associated with BMI, non-communicable risk and its prevalence, indicated the needs of early and routine NCDs risk assessment among workers. ${ }^{12,22-25} \mathrm{~A}$ systematic review and meta-analysis show that health checks are associated with little but significant improvement in total cholesterol, systolic and diastolic blood pressure, and body mass index, particularly among those who were high risk. ${ }^{32}$

In recent years, oil and gas companies were invested in worksite health promotion initiative aimed to improve workers' health and well-being including diet and nutrition. However, the evidence is rather limited. Some results published in projects book and reports ${ }^{33-35}$, and other initiatives probably remain unpublished, therefore cannot be included in this review. There is a need for collaboration between the companies and academics to design the health promotion program based on evidence, so that the outcome and cost effectiveness can be measured properly.

Three papers investigated the effect of education/counseling in oil and gas workers was identified. A qualitative study on offshore oil and gas worker in Scotland highlighted that knowledge and beliefs about consequences of outcomes related with healthy eating may influence their food choices. For instance, when workers believe that poor sleep quality is related with unhealthy eating habits, it may increase the possibility of eating healthily. ${ }^{19}$ 
Among reviewed studies, two longitudinal studies found significant improvement in physical activity/physical fitness but not in dietary intake and obese status. These studies were provided counseling sessions that cover multiple aspect of health promotion, including nutrition and physical activity. ${ }^{26,27}$ The third study was a randomized clinical trials (RCT) on nutrition education targeting workers and their family, after 3-month of followup there were significant improvement in dietary intake, body weight and BMI. ${ }^{28}$

The prospective cohort study in Finland oil refinery employees was give the intervention group 2-hour lecture session in energy intake and consumption, BMI, metabolism of macro and micronutrient, and healthy cooking methods delivered by occupational health nurse. Printed education materials were distributed after the course, however the monitoring of diet during 3-year of follow-up was not further discussed in the article. Compared to one shoot nutrition education, physical activity training in this study was more extensive, consist of 20 weeks of training guided by instructor at the beginning of the study and measurement of physical fitness every six months. ${ }^{26}$

Similar concern was identified from Brazilian oil workers cohort study. During the four-year of interdisciplinary health promotion strategies, each year, workers only received one consultation session with nutritionist on their food profiles and how to improve its quality. The counseling session was insisted to increase workers self-care towards their health. ${ }^{27}$ Contrary to that, an RCT targeted Iranian oil and gas workers gives five nutrition education session through lecture and group discussions. The study was conducted for three-month period. When there was no education session throughout the week, question and answer sessions and telephone followup were conducted to strengthen workers understanding towards education materials. ${ }^{28}$ This study resulted in significant improvement in nutrition knowledge and CVD risks related outcomes. However due to relatively short followup durations, the probability of weight regains, and relapse of unhealthy behaviors could not be identified.

The results from longitudinal and experimental studies indicated that worksite health promotion should not be established as one shoot projects, but to be inserted as a continuous process that attached to workers daily life. Aside from modifying workers knowledge and beliefs towards education and counseling, the finding from reviewed crosssectional studies give hints on the modifiable worksite related factors that could be improved the diet, eating habits and obese status among workers, including peer influence, food availability, and selfcare.

Social influence was one of the behaviors change domains identified in oil and gas workers. Both negative and positive influence from peers were affecting their exercise and eating habits. In the case of positive influence, motivation from colleagues, the availability of supportive partner while exercising and healthy eating play an important role. ${ }^{19}$ A randomized controlled trial in Malaysian obese adults worked in the university show that compared to nutrition counseling, group support lifestyle modification was more effective in achieving weight loss, improving self-efficacy towards their weight, friend social support, and quality of life. ${ }^{36}$

Promotion of health self-care is suggested, particularly for offshore worker that live in remote or isolated environment. Workers willpower to eat healthily and to exercise regularly, including setting goals, planning and self-monitoring helps worker to be prepared and stay on track. For instance, bring their own healthy snack, records their calories intake and exercise history were found to be important in order to survive in the obesogenic environment of offshore lifestyle. ${ }^{19}$

Foods in oil and gas workplace are usually available at all hours throughout the days. Plentiful of pleasant energy-dense foods prepared with significant amount of salt and fat are served..$^{10}$ It is natural to grab the nearest available food when in hunger, therefore food provision is a key influence on workers healthy eating behavior. To make healthy food available and probably restrict eating times were suggested to positively impact eating behavior. ${ }^{19}$ Improving healthier food choices at work found to be effectively increase fruit and vegetable consumption, reduce fat intake, promote weight loss and reduce blood cholesterol level. ${ }^{37}$ However, changes in environmental conditions, both to make healthier food available and provide comfortable exercise facility are considered 
expensive than informational and behavioral strategies. Therefore, cost-effectiveness analysis is needed prior to these environmental changes. ${ }^{38}$

\section{Conclusion}

To summarize, the analysis of the diet implied high intake of fat, particularly saturated fat and cholesterol; with low intake of dietary fiber. Type of food frequently consumed by workers were animal protein sources food, particularly high in meat and low in fish; sweets and snacks, sweetened beverages, coffee, and tea with added sugars. Fatigue, boredom, and inadequate sleep may influence unhealthy food choices. Potential intervention to improve diet, eating habits and obesity among oil and gas workers identified in this review consist of three main components ${ }^{38}$ : (1) Informational messages, improve knowledge and beliefs through education, counseling, and other delivery methods; (2) behavioral and social skills, promote health-self-care, family and peer supports, (3) environmental changes and policy, provide healthy food options, cafeterias time restriction and exercise facility. Finally, it is worthy to note that worksite health promotions are potential to improve nutrition, physical activity, and health related outcomes.

This systematic review provides snapshots of diet, eating habits, and obesity among oil and gas worker, and its possible improvement strategies. Although there seems to be several studies reviewing diet and obesity in workers, we manage to emphasize the review of this aspects in rarely studied oil and gas population since the beginning of time until the recent published study. However, we must confirm that there are still many research gaps, including the lack of longitudinal studies on dietary patterns and nutrient intake and scarcity of RCTs in this populations. Ten from thirteen included studies focused on populations in developed countries, which may receive universal health coverage and better-quality health services that may be counteracted workers lifestyle habits. Other limitation relates to the screening, and language. Screening of articles was performed by one author. Several article in Italian and Chinese language was unable to review due to language restriction.
Moreover, as in most review studies, publication bias might be an issue. 
Table 1. Studies exploring factors influencing diet, eating habits in oil and gas workers

\begin{tabular}{|c|c|c|c|c|c|}
\hline $\begin{array}{c}\text { Author } \\
\text { (year) }\end{array}$ & $\begin{array}{l}\text { Study design } \\
\text { (sample size) }\end{array}$ & Population & $\begin{array}{l}\text { Assessment of } \\
\text { dietary intake }\end{array}$ & Description of worker's dietary intake & Influencing factors \\
\hline $\begin{array}{l}\text { Oshaug et } \\
\text { al (1992) }\end{array}$ & $\begin{array}{l}\text { Cross-sectional } \\
(\mathrm{n}=203, \quad 4 \% \\
\text { females })\end{array}$ & $\begin{array}{l}\text { Offshore worker } \\
\text { in North Sea oil } \\
\text { installations, } \\
\text { Norway }\end{array}$ & $\begin{array}{l}\text { standard } 24 \mathrm{~h} \\
\text { dietary recall, and } \\
\text { additional questions } \\
\text { regarding } \\
\text { underlying factors } \\
\text { influencing the diet. }\end{array}$ & $\begin{array}{l}\text { Type of food found to be important in workers diet } \\
\text { were meat, vegetables, fresh fruits, seafood, fried fries, } \\
\text { eggs, and ice-cream. Coffee, fruit juice and soft drinks } \\
\text { were frequently consumed beverages. Workers } \\
\text { average daily intake of energy was } 2916 \pm 69 \mathrm{kcal} \text {, } \\
\text { contributed from } 44 \% \text { of fat, } 39 \% \text { of carbohydrate, and } \\
17 \% \text { of protein intake. Workers diet was high in fat and } \\
\text { cholesterol but low in dietary fiber. }\end{array}$ & $\begin{array}{l}\text { High contribution of fat towards } \\
\text { energy in the 5-month food stocks. }\end{array}$ \\
\hline $\begin{array}{l}\text { Christina } \\
\text { and Sartika } \\
(2011)\end{array}$ & $\begin{array}{l}\text { Cross-sectional } \\
(\mathrm{n}=378)\end{array}$ & $\begin{array}{l}\text { Onshore oil and } \\
\text { gas workers, } \\
\text { Indonesia }\end{array}$ & $\begin{array}{l}\text { One-day } 24 \text { dietary } \\
\text { recall }\end{array}$ & $\begin{array}{l}\text { More than half of workers consumed total fat higher } \\
\text { than its recommended value, almost half respondents } \\
\text { consume }>300 \mathrm{mg} \text { of cholesterol/day and only } 12.4 \% \\
\text { workers have adequate intake of dietary fiber. }\end{array}$ & $\begin{array}{l}\text { Multivariate analysis showed that } \\
\text { age, level of education, employment } \\
\text { status, energy, carbohydrate, and } \\
\text { dietary fiber intake were associated } \\
\text { with obesity. }\end{array}$ \\
\hline $\begin{array}{l}\text { Health et al } \\
(2016)\end{array}$ & $\begin{array}{l}\text { Cross-sectional } \\
(\mathrm{n}=131, \text { O\&G } \\
\text { worker }=28 \text { male } \\
\text { and } 4 \% \text { female })\end{array}$ & $\begin{array}{l}\text { Workers engaged } \\
\text { in shift work } \\
\text { schedule, } \\
\text { Australia }\end{array}$ & $\begin{array}{lr}\text { Validated } & \text { semi- } \\
\text { quantitative } & \text { self- } \\
\text { administered } & \text { food } \\
\text { frequency } & \\
\text { questionnaire } & \\
\text { (FFQ) } & \end{array}$ & $\begin{array}{l}\text { Contribution of fat and saturated fat towards energy } \\
\text { intake among oil and gas workers were exceeded the } \\
\text { recommended value ( } 34.5 \text { and } 14.1 \% \text {, respectively) } \\
\text { however its slightly lower than other shift workers } \\
\text { (printing, postal and nursing). }\end{array}$ & $\begin{array}{l}\text { Multivariate analysis showed that } \\
\text { sleep duration, fatigue, and shift } \\
\text { schedule were associated with } \\
\text { dietary intake of shift workers. }\end{array}$ \\
\hline $\begin{array}{l}\text { Smith et al } \\
(2018)\end{array}$ & $\begin{array}{l}\text { Qualitative semi- } \\
\text { structured } \\
\text { telephone } \\
\text { interview } \\
(\mathrm{n}=16)\end{array}$ & $\begin{array}{l}\text { Offshore oil and } \\
\text { gas workers, } \\
\text { Scotland }\end{array}$ & $\begin{array}{l}\text { Qualitative } \\
\text { interview }\end{array}$ & $\begin{array}{l}\text { Living in the offshore settings and attached to the } \\
\text { unhealthy lifestyle habits was an automatic process, } \\
\text { however workers perceived that eating patterns and } \\
\text { physical activity were behaviors that required to } \\
\text { change. }\end{array}$ & $\begin{array}{l}\text { Knowledge, intentions, memory, } \\
\text { attention and decision-making } \\
\text { process, environmental context and } \\
\text { resources, social influences, } \\
\text { emotional and behavioral regulation } \\
\text { were associated with those } \\
\text { behaviors. }\end{array}$ \\
\hline
\end{tabular}


Table 2. Studies exploring obesity in oil and gas workers

\begin{tabular}{|c|c|c|c|c|}
\hline $\begin{array}{c}\text { Author } \\
\text { (year) }\end{array}$ & $\begin{array}{l}\text { Study design } \\
\text { (sample size) }\end{array}$ & Population & Obesity prevalence & Findings \\
\hline $\begin{array}{l}\text { Parkes } \\
(2003)\end{array}$ & $\begin{array}{l}\text { Cross-sectional } \\
(\mathrm{n}=1581) \text { and } \\
\text { longitudinal } \\
(\mathrm{n}=354)\end{array}$ & $\begin{array}{l}\text { Male offshore } \\
\text { workers, United } \\
\text { Kingdom (UK) }\end{array}$ & $\begin{array}{l}\text { The prevalence of obesity and overweight in baseline } \\
\text { were } 7.5 \text { and } 47.3 \% \text {, respectively. Mean BMI and obesity } \\
\text { prevalence were significantly increased for } 10 \text { years } \\
\text { follow-up. Baseline and end line BMI }\left(\mathrm{kg} / \mathrm{m}^{2}\right) \text { were } \\
25.6 \pm 2.8 \text { and } 26.6 \pm 2.9 \text {, respectively. }\end{array}$ & $\begin{array}{l}\text { Non-smokers, sedentary jobs, lower education, younger } \\
\text { workers and those who are married have higher Body Mass } \\
\text { Index (BMI). }\end{array}$ \\
\hline $\begin{array}{l}\text { Al-Asi } \\
(2003)\end{array}$ & $\begin{array}{l}\text { Cross-sectional } \\
(\mathrm{n}=3282,15 \% \\
\text { female })\end{array}$ & $\begin{array}{l}\text { Oil workers, } \\
\text { Kuwait }\end{array}$ & $\begin{array}{l}\text { Overall prevalence of overweight and obesity among } \\
\text { workers was } 75 \% \text {, based on gender, the prevalence was } \\
\text { higher in male workers }(79 \%) \text { than females }(56 \%) \text {. }\end{array}$ & $\begin{array}{l}\text { Looking into the type of work, overweight and obesity level } \\
\text { was higher in field workers }(78 \%) \text { than office workers } \\
(72 \%) \text {. Among those type of workers, field workers have } \\
\text { higher prevalence of physical inactivity and diabetes }(65 \% \\
\text { and } 18 \% \text {, respectively) than office worker ( } 56 \% \text { and } 15 \% \text {, } \\
\text { respectively). }\end{array}$ \\
\hline $\begin{array}{l}\text { Poorabdian } \\
(2013)\end{array}$ & Cohort $(n=500)$ & $\begin{array}{l}\text { Male } \\
\text { petrochemical } \\
\text { workers, Iran }\end{array}$ & Mean BMI of workers was $29.93 \pm 7.3 \mathrm{~kg} / \mathrm{m}^{2}$ & $\begin{array}{l}\text { Overweight and obese workers were having higher job } \\
\text { demand and low control towards their jobs. A significant } \\
\text { association was found between job control and demand } \\
\text { with cardiovascular risk factors including BMI, } \\
\text { hypertension, hyperlipidemia, and smoking. }\end{array}$ \\
\hline $\begin{array}{l}\text { Mannocci } \\
\text { et al. } \\
(2015)\end{array}$ & $\begin{array}{l}\text { Observative } \\
\text { cross-sectional } \\
(\mathrm{n}=1073, \quad 1 \% \\
\text { female) }\end{array}$ & $\begin{array}{l}\text { Oil and gas and } \\
\text { energy company } \\
\text { workers, Italy }\end{array}$ & $\begin{array}{l}\text { The prevalence of overweight and obesity was } 49.7 \text { and } \\
12.7 \% \text {; hypertension } 35.5 \% \text {, high Fasting Blood Glucose } \\
\text { (FBG) } 3.0 \% \text {; high cholesterol and high triglycerides } 24.3 \\
\text { and } 29.7 \% \text {, respectively. Mean BMI was } 26.26 \pm 3.4 \\
\mathrm{~kg} / \mathrm{m}^{2} \text {. }\end{array}$ & $\begin{array}{l}\text { Major cardiovascular risk factors were significantly higher } \\
\text { in older group and its worsened by age, shown the needs of } \\
\text { early risk assessment among this population. }\end{array}$ \\
\hline $\begin{array}{l}\text { Stewart et } \\
\text { al (2017) }\end{array}$ & $\begin{array}{l}\text { Observative } \\
\text { cross-sectional } \\
(\mathrm{n}=558)\end{array}$ & $\begin{array}{l}\text { Male offshore } \\
\text { workers, United } \\
\text { Kingdom (UK) }\end{array}$ & $\begin{array}{l}\text { Compared to anthropometric surveillance data of UK } \\
\text { offshore workers } 30 \text { years ago, today workers } \\
\text { experienced increased body weight }(+13.9 \mathrm{~kg}) \text {, body } \\
\text { height }(+3.1 \mathrm{~cm}) \text { and mean BMI }\left(\mathrm{kg} / \mathrm{m}^{2}\right) \text { changes from } \\
24.9 \text { to } 28.1 \text {, escalating obesity and overweight } \\
\text { prevalence by } 6 \text { and } 24 \% \text {, respectively. }\end{array}$ & $\begin{array}{l}\text { This could be contributed to the obesogenic environment of } \\
\text { offshore workplace, including 24-hour availability of } \\
\text { energy-dense and appetizing foods accompanied by } \\
\text { mechanization at works. }\end{array}$ \\
\hline $\begin{array}{l}\text { Baghshini } \\
\text { et al (2017) }\end{array}$ & $\begin{array}{l}\text { Cross-sectional } \\
(\mathrm{n}=670)\end{array}$ & $\begin{array}{l}\text { Male gas refinery } \\
\text { employees, Iran }\end{array}$ & $\begin{array}{l}\text { It is easier to find gas refinery employees with Metabolic } \\
\text { Syndrome, obesity, abdominal obesity, high FBG and } \\
\text { high Blood Pressure (BP) compared to workers in } \\
\text { nonindustrial environment. Mean BMI of gas employees } \\
\text { was } 26.47 \pm 3.9 \mathrm{~kg} / \mathrm{m}^{2} \text {. }\end{array}$ & $\begin{array}{l}\text { Possible internal and external causes including air and } \\
\text { chemical pollutants, exposed to noise and heat, and lifestyle } \\
\text { habits particularly dietary intake, physical activity and } \\
\text { sleep patterns. }\end{array}$ \\
\hline
\end{tabular}


Table 3. Studies done to improve diet and obesity status in oil and gas workers

\begin{tabular}{|c|c|c|c|c|}
\hline $\begin{array}{c}\text { Author } \\
\text { (year) }\end{array}$ & $\begin{array}{c}\text { Study design } \\
\text { (follow-up) }\end{array}$ & Population & Grouping & Main results \\
\hline $\begin{array}{l}\text { Talvi et } \\
\text { al (1999) }\end{array}$ & $\begin{array}{l}\text { Prospective } \\
\text { cohort } \\
(3 \text { years })\end{array}$ & $\begin{array}{l}\text { Employees in oil } \\
\text { refinery, Finland }\end{array}$ & $\begin{array}{l}\text { Group A }(n=365) \text { received special counselling } \\
\text { according to their needs based on previous health } \\
\text { assessment in the areas of dietary habits, obesity, blood } \\
\text { pressure and/or serum lipids from regular staff } \\
\text { (occupational health nurse and physician). Workers } \\
\text { also received personalized exercise plan made by } \\
\text { external physical fitness instructor. } \\
\text { Group B (n=433): Worker that participated in health } \\
\text { assessment and received written results with printed } \\
\text { health promotion (HP) material }\end{array}$ & $\begin{array}{l}\text { The counselling effectively improved Group A's physical } \\
\text { fitness, while there were no changes in Group B. Explanatory } \\
\text { variables for physical activity were level of education, value } \\
\text { tending of health and participation in the counselling. During } \\
\text { a three-year follow-up there were changes of worker HP needs. } \\
\text { However, the assessment of HP needs only occurred once in } \\
\text { the beginning of the study. } \\
\text { Author conclusion: The study has high participation rate and } \\
\text { low drop-out rates, workers also show positive attitude toward } \\
\text { health promotion, however the changes of behaviors were } \\
\text { uncertain. }\end{array}$ \\
\hline $\begin{array}{l}\text { Viterbo } \\
\text { et al } \\
(2019)\end{array}$ & $\begin{array}{l}\text { Retrospective } \\
\text { cohort } \\
(9 \text { years })\end{array}$ & $\begin{array}{l}\text { Male workers in oil } \\
\text { industry, Brazil }\end{array}$ & $\begin{array}{l}\text { Intervention }(\mathrm{n}=1736) \text { : Worker in Bahia that received } \\
\text { interdisciplinary health promoting strategies during } \\
\text { annual medical assessment aimed to improve workers } \\
\text { self-care towards their health and control the } \\
\text { development of non- communicable diseases. } \\
\text { Control }(n=54211) \text { : workers in Brazil excluding those } \\
\text { in Bahia }\end{array}$ & $\begin{array}{l}\text { Intervention group showed significant decrease in number of } \\
\text { smokers, periodontal disease, absence days and increase in } \\
\text { number of physically active workers. Small improvement in } \\
\text { obesity status and hyperglycemia. However, there were no } \\
\text { changes in blood pressure and coronary risks. } \\
\text { Author conclusion: Interdisciplinary health promotion based } \\
\text { on population needs associated with improvement of health } \\
\text { and productivity. }\end{array}$ \\
\hline $\begin{array}{l}\text { Hassani } \\
\text { et al } \\
(2020)\end{array}$ & $\begin{array}{l}\text { Randomized } \\
\text { clinical trial } \\
(3 \text { months })\end{array}$ & $\begin{array}{l}\text { Male employees } \\
\text { with dyslipidemia in } \\
\text { petrochemical } \\
\text { company, Iran }\end{array}$ & $\begin{array}{l}\text { Intervention }(n=48) \text { : workers received routine medical } \\
\text { care and five education session delivered by registered } \\
\text { nutritionist covered three main topics }(1) \text { cardiovascular } \\
\text { diseases }(C V D) \text {, obesity and weight management }(2) \\
\text { healthy diet and physical activity ( } 3 \text { ) conducted for } \\
\text { family member about their roles to support workers } \\
\text { health. } \\
\text { Control }(n=43) \text { : workers received routine medical care }\end{array}$ & $\begin{array}{l}\text { The education brings improvement in fasting blood sugar and } \\
\text { homocysteine, significant decrease in body weight and BMI } \\
\text { (but not in body fat percentage) and positive effects in the } \\
\text { nutritional knowledge and dietary intakes. After the } \\
\text { interventions, there was significant declines on education } \\
\text { groups unhealthy food consumption, such as sweet and } \\
\text { pastries, soft drinks, and sugars. } \\
\text { Author conclusion: Worksite nutrition education session was } \\
\text { beneficial to improve knowledge and control the CVD risk } \\
\text { factors. }\end{array}$ \\
\hline
\end{tabular}




\section{Conflict of Interest}

Authors declared no conflict of interest regarding this article.

\section{Acknowledgement}

Very special gratitude is extended to Dr. Ir. Umi Fahmida, M.Sc and Prof. dr. Muchtaruddin Mansyur, MS, Sp.Ok, Ph.D for their support in ideas, concept, and insight throughout the time of author's study period. Their previous inputs are strong basis for author to write this article. The authors thank the Universitas Indonesia for granted access to the Scopus website that used in literature search processes.

\section{Open Access}

This article is distributed under the terms of the Creative Commons Attribution 4.0 International Licence (http://creativecommons.org/licenses/by/4.0/), which permits unrestricted use, distribution, and reproduction in any medium, provided you give appropriate credit to the original author(s) and the source, provide a link to the Creative Commons license, and indicate if changes were made.

\section{References}

1. Statistics WE. World Energy Statistics 2018. Int Energy Agency. 2018;

2. Mette J, Garrido MV, Harth V, Preisser AM, Mache S. "It ' s still a great adventure " - exploring offshore employees ' working conditions in a qualitative study. 2017;1-13.

3. Amani R, Gill T. Shiftworking, nutrition and obesity: Implications for workforce health- a systematic review. Asia Pac J Clin Nutr. 2013;22(4):505-15.

4. Preiss K, Brennan L, Clarke D. A systematic review of variables associated with the relationship between obesity and depression. Obes Rev. 2013;14(11):90618.

5. Sun M, Feng W, Wang F, Li P, Li Z, Li M, et al. Metaanalysis on shift work and risks of specific obesity types. Obes Rev. 2018;19(1):28-40.

6. Souza RV, Sarmento RA, de Almeida JC, Canuto R. The effect of shift work on eating habits: A systematic review. Scand J Work Environ Heal. 2019;45(1):7-21.

7. Chen WQ, Wong TW, Yu ITS. Association of occupational stress and social support with healthrelated behaviors among Chinese offshore oil workers.
J Occup Health. 2008;

8. Fajrin VC. The Overview of Mental Workload of Health Safety and Environment Workers in Oil and Gas Industry Gambaran Berat Beban Kerja Mental Pekerja Industri Minyak dan Gas. Indones J Occup Saf Heal. 2020;9(2):154-62.

9. Mannocci A, Pignalosa S, Nicosia V, Saulle R, Sernia S, La Torre G. Cardiovascular Diseases Risk Factors in oil and gas workers: A ten years observational retrospective cohort. Ann di Ig. 2016;28(2):122-32.

10. Stewart AD, Ledingham RL, Furnace G, Williams H, Nevill AM. Shape change and obesity prevalence among male UK offshore workers after 30 years: New insight from a 3D scanning study. Am J Hum Biol. 2017;29(4):1-7.

11. Baghshini MR, Nikbakht-Jam I, Mohaddes-Ardabili H, Pasdar A, Avan A, Tayefi M, et al. Higher prevalence of metabolic syndrome among male employees of a gas refinery than in their counterparts in nonindustrial environments. Asian Biomed. 2017;11(3):227-34.

12. Mannocci A, Pignalosa S, Saulle R, Sernia S, De Sanctis S, Consentino $\mathrm{M}$, et al. Prevalence of major cardiovascular risk factors among oil and gas and energy company workers. Ann Ist Super Sanita. 2015;

13. Ni Mhurchu C, Aston LM, Jebb SA. Effects of worksite health promotion interventions on employee diets: A systematic review. BMC Public Health. 2010;

14. Tsai SP, Ahmed FS, Wendt JK, Bhojani F, Donnelly RP. The Impact of Obesity on Illness Absence and Productivity in an Industrial Population of Petrochemical Workers. Ann Epidemiol. 2008;18(1):814.

15. Goldgruber J, Ahrens D. Effectiveness of workplace health promotion and primary prevention interventions: A review. Journal of Public Health. 2010.

16. Cancelliere C, Cassidy JD, Ammendolia C, Côté P. Are workplace health promotion programs effective at improving presenteeism in workers? A systematic review and best evidence synthesis of the literature. BMC Public Health. 2011;

17. Ruffner R, Riedel JE, Lynch W, Baase C, Hymel P, Peterson KW. The effect of disease prevention and health promotion on workplace productivity: A literature review. American Journal of Health Promotion. 2001.

18. Rongen A, Robroek SJW, Van Lenthe FJ, Burdorf A. Workplace health promotion: A meta-analysis of effectiveness. American Journal of Preventive Medicine. 2013.

19. Smith KG, Paudyal V, Quinn F, Klein S, Stewart D. Offshore workers and health behaviour change: An exploration using the Theoretical Domains Framework. Int Marit Health. 2018;69(4):248-56.

20. Oshaug A, Østgård LI, Trygg KU. Diet among oilworkers on off-shore oil installations in the Norwegian sector of the North Sea. Br J Nutr. 1992;68(1):11-9.

21. Heath G, Coates A, Sargent C, Dorrian J. Sleep Duration and Chronic Fatigue Are Differently Associated with the Dietary Profile of Shift Workers. 
2016;1-15.

22. Poorabdian S, Mirlohi AH, Habibi E, Shakerian M. Association between job strain (high demand-low control) and cardiovascular disease risk factors among petrochemical industry workers. Int $\mathrm{J}$ Occup Med Environ Health. 2013;26(4):555-62.

23. Christina D, Ayu R, Sartika D. Obesitas pada Pekerja Minyak dan Gas Obesity among Oil and Gas Workers. Natl Public Heal J. 2011;6(3):104-10.

24. Parkes KR. Demographic and lifestyle predictors of body mass index among offshore oil industry workers: Cross-sectional and longitudinal findings. Occup Med (Chic Ill). 2003;53(3):213-21.

25. Al-Asi T. Overweight and obesity among Kuwait Oil Company employees: A cross-sectional study. Occup Med (Chic Ill). 2003;53(7):431-5.

26. Talvi AI, Järvisalo JO, Knuts LR. A health promotion programme for oil refinery employees: Changes of health promotion needs observed at three years. Occup Med (Chic Ill). 1999;49(2):93-101.

27. Viterbo LMF, Dinis MAP, Vidal DG, Costa AS. Implementation of an interdisciplinary approach to promote workers global health status in the oil industry, Brazil (2006-2015). Int J Environ Res Public Health. 2019;16(12).

28. Hassani B, Amani R, Haghighizadeh MH, Araban M. A priority oriented nutrition education program to improve nutritional and cardiometabolic status in the workplace: A randomized field trial. J Occup Med Toxicol. 2020;15(1):1-9.

29. Bonham MP, Bonnell EK, Huggins CE. Energy intake of shift workers compared to fixed day workers: A systematic review and meta-analysis. Chronobiology International. 2016.

30. Paper FAOF. Fats and fatty acids in human nutrition. Report of an expert consultation. Vol. 91, FAO food and nutrition paper. 2010. 1-166 p.

31. Antunes LC, Levandovski R, Dantas G, Caumo W, Hidalgo MP. Obesity and shift work: Chronobiological aspects. Nutr Res Rev. 2010;23(1):155-68.

32. Si S, Moss JR, Sullivan TR, Newton SS, Stocks NP. Effectiveness of general practice-based health checks: A systematic review and meta-analysis. British Journal of General Practice. 2014.

33. Mearns K, Hope L. Health and well-being in the offshore environment: The management of personal health. Psychology. 2005;

34. Corpes A. Offshore installations benefit from nutrition training programmes. Vol. 133. 2015.

35. Mearns K, Hope L, Reader T. Health and well-being in the offshore environment The role of the organisational support Prepared by the University of Aberdeen The role of the organisational support. Rural Remote Health. 2018;18(2).

36. Jamal SN, Moy FM, Mohamed MNA, Mukhtar F. Effectiveness of a group support lifestyle modification (GSLiM) programme among obese adults in workplace: A randomised controlled trial. PLoS One. 2016;11(8):1-22.
37. Schliemann D, Woodside J V. The effectiveness of dietary workplace interventions: A systematic review of systematic reviews. Public Health Nutr. 2019;22(5):942-55.

38. Anderson LM, Quinn TA, Glanz K, Ramirez G, Kahwati LC, Johnson DB, et al. The Effectiveness of Worksite Nutrition and Physical Activity Interventions for Controlling Employee Overweight and Obesity. A Systematic Review. Am J Prev Med [Internet]. 2009;37(4):340-57. Available from: http://dx.doi.org/10.1016/j.amepre.2009.07.003 